\title{
Stimulation of Acid Phosphatase Synthesis and Secretion in Ochromonas danica by Chloramphenicol Base
}

\author{
By S. AARONSON AND N. J. PATNI \\ Biology Department, Queens College, City University of New York, \\ Flushing, New York 11376, U.S.A.
}

(Received 5 October 1977)

\begin{abstract}
A non-dividing suspension of Ochromonas danica secreted an acid phosphatase into its medium. This secretion was significantly stimulated by chloramphenicol base, unaffected by chloramphenicol or molecules resembling it, and inhibited by cycloheximide. Chloramphenicol base also stimulated total enzyme synthesis. The mechanism of stimulation by chloramphenicol base remains unknown.
\end{abstract}

\section{INTRODUCTION}

Several inhibitors of protein synthesis can sometimes stimulate protein synthesis: for example, chloramphenicol stimulates protein synthesis in the soluble cytoplasmic pool and most mitochondrial proteins (including cytochrome $c$ but not cytochrome $a+a_{3}$ ) in rat liver (Kadenbach, 1971); cycloheximide stimulates the activity of tyrosine aminotransferase (Fiala \& Fiala, 1965; Benson \& Young, 1968) and rat liver uridine kinase (Čihak, 1975); and puromycin stimulates liver ornithine decarboxylase activity (Beck, Bellantone \& Canellakis, 1973). The effect of these compounds on protein synthesis was not determined.

Cycloheximide has been assumed to be a specific inhibitor of cytoplasmic ribosomal protein synthesis (Sisler \& Siegel, 1967). Recently, however, appreciable evidence has accumulated indicating that cycloheximide may also inhibit RNA synthesis, respiration, absorption, amino-acid uptake etc. (McMahon, 1975). Cycloheximide also inhibits secretion of proteins in some organisms and cells, e.g. asparaginase in Saccharomyces cerevisiae (Dunlop \& Roon, 1975), but not in others, e.g. $\alpha$-amylase in barley (Varner \& Mense, 1972). Acid phosphatase synthesis is much more sensitive to cycloheximide than is its secretion in in vitro tobacco cell cultures (Ueki \& Sato, 1971). In several mammalian tissue culture lines the secretion of one enzyme, deoxyribonuclease, is inhibited by cycloheximide but not another enzyme, alkaline phosphatase (Nose et al., 1974).

Recently we described that the lower eukaryotic phytoflagellate Ochromonas danica, when suspended in starvation medium, secreted acid phosphatase in a linear fashion (Aaronson \& Patni, 1976) and this secretion could be stimulated by specific organic phosphates (Patni \& Aaronson, 1977). We report here that chloramphenicol base (chloramphenicol without the dichloroacetamido side chain) and, much less effectively, chloramphenicol, stimulate acid phosphatase synthesis and secretion in $O$. danica whereas cycloheximide appears to inhibit both protein synthesis and secretion of the enzyme.

\section{METHODS}

Organism, growth and harvesting conditions. Ochromonas danica $\mathrm{L} 933 / 2$ Pringsheim was maintained and grown as described by Patni \& Aaronson (1974). Unless otherwise stated, harvesting, centrifugation procedures and preparation of cell extracts for enzyme assays were as described earlier (Patni \& Aaronson, 1974); intracellular enzyme activity was measured on cell homogenates. Procedures for the short-term secretion 


\section{Table 1. Effect of chloramphenicol and chloramphenicol base on acid phosphatase synthesis and secretion in Ochromonas danica}

Washed cells were resuspended in starvation medium (Aaronson \& Patni, 1976) containing different concentrations of chloramphenicol or chloramphenicol base. At intervals, acid phosphatase activity was determined using p-nitrophenyl phosphate as an assay substrate. Enzyme activity at zero time was taken as $100 \%$; figures in parentheses represent relative intracellular activity.

\begin{tabular}{|c|c|c|c|c|}
\hline \multirow[b]{2}{*}{ Addition } & \multirow{2}{*}{$\begin{array}{c}\text { Concn } \\
\text { (mM) }\end{array}$} & \multicolumn{3}{|c|}{ over zero-time sample after: } \\
\hline & & $2 \mathrm{~h}$ & $4 \mathrm{~h}$ & $6 \mathrm{~h}$ \\
\hline None & & $\begin{array}{c}148 \cdot 5 \pm 15 \cdot 6 \\
(97 \cdot 7 \pm 1 \cdot 05)\end{array}$ & $\begin{array}{c}202 \cdot 6 \pm 17 \cdot 5 \\
(101 \cdot 1 \pm 2 \cdot 15)\end{array}$ & $\begin{array}{c}250 \cdot 4 \pm 22 \cdot 5 \\
(105 \cdot 8 \pm 2 \cdot 1)\end{array}$ \\
\hline \multirow[t]{4}{*}{ Chloramphenicol base } & $0 \cdot 01$ & $\begin{array}{l}153 \cdot 2 \pm 17 \cdot 5 \\
(98 \cdot 8 \pm 2 \cdot 1)\end{array}$ & $\begin{array}{c}210 \cdot 3 \pm 17 \cdot 0 \\
(105 \cdot 7 \pm 1 \cdot 0)\end{array}$ & $\begin{array}{c}273 \cdot 8 \pm 11 \cdot 0 \\
(111 \cdot 4 \pm 3 \cdot 2)\end{array}$ \\
\hline & $0 \cdot 04$ & $\begin{array}{c}157 \cdot 4 \pm 15 \cdot 0 \\
(101 \cdot 2 \pm 1 \cdot 0)\end{array}$ & $\begin{array}{c}215 \cdot 8 \pm 13 \cdot 5 \\
(105 \cdot 8 \pm 2 \cdot 1)\end{array}$ & $\begin{array}{c}286 \cdot 8 \pm 12 \cdot 5 \\
(116 \cdot 4 \pm 2 \cdot 1)\end{array}$ \\
\hline & $0 \cdot 1$ & $\begin{array}{c}160 \cdot 2 \pm 12 \cdot 0 \\
(100 \cdot 7 \pm 3 \cdot 2)\end{array}$ & $\begin{array}{c}219 \cdot 2 \pm 15 \cdot 0 \\
(108 \cdot 5 \pm 3 \cdot 3)\end{array}$ & $\begin{array}{c}296 \cdot 6 \pm 14 \cdot 2 \\
(120 \cdot 3 \pm 1 \cdot 2)\end{array}$ \\
\hline & $1 \cdot 0$ & $\begin{array}{c}173 \cdot 5 \pm 15 \cdot 0 \\
(102 \cdot 5 \pm 2 \cdot 1)\end{array}$ & $\begin{array}{c}294 \cdot 5 \pm 15 \cdot 5 \\
(110 \cdot 8 \pm 3 \cdot 2)\end{array}$ & $\begin{array}{r}367 \cdot 1 \pm 17 \cdot 5 \\
(122 \cdot 1 \pm 3 \cdot 5)\end{array}$ \\
\hline \multirow[t]{4}{*}{ Chloramphenicol } & $0 \cdot 01$ & $\begin{array}{l}148 \cdot 5 \pm 15 \cdot 2 \\
(99 \cdot 4 \pm 3 \cdot 3)\end{array}$ & $\begin{array}{c}202 \cdot 6 \pm 17 \cdot 5 \\
(103 \cdot 0 \pm 4 \cdot 2)\end{array}$ & $\begin{array}{r}258 \cdot 5 \pm 20 \cdot 7 \\
(114 \cdot 7 \pm 5 \cdot 7)\end{array}$ \\
\hline & 0.03 & $\begin{array}{c}152.5 \pm 17 \cdot 0 \\
(97.6 \pm 2.4)\end{array}$ & $\begin{array}{c}212 \cdot 4 \pm 22 \cdot 0 \\
(104 \cdot 9 \pm 4 \cdot 5)\end{array}$ & $\begin{array}{r}267 \cdot 0 \pm 18 \cdot 7 \\
(115 \cdot 5 \pm 6 \cdot 2)\end{array}$ \\
\hline & $0 \cdot 1$ & $\begin{array}{l}160.5 \pm 12.5 \\
(97.8 \pm 1.9)\end{array}$ & $\begin{array}{c}220 \cdot 5 \pm 18 \cdot 5 \\
(107 \cdot 9 \pm 4 \cdot 2)\end{array}$ & $\begin{array}{c}270 \cdot 2 \pm 19 \cdot 0 \\
(122 \cdot 5 \pm 7 \cdot 2)\end{array}$ \\
\hline & $1 \cdot 0$ & $\begin{array}{c}163 \cdot 5 \pm 16 \cdot 5 \\
(99 \cdot 2 \pm 2 \cdot 8)\end{array}$ & $\begin{array}{c}225 \cdot 3 \pm 17 \cdot 5 \\
(110 \cdot 0 \pm 3 \cdot 8)\end{array}$ & $\begin{array}{l}282 \cdot 5 \pm 21 \cdot 2 \\
(123 \cdot 6 \pm 6 \cdot 5)\end{array}$ \\
\hline
\end{tabular}

experiments have been described elsewhere (Aaronson \& Patni, 1976). Details of the radioactive labelling experiments with [ $\left.{ }^{3} \mathrm{H}\right]$ leucine were described by Patni \& Aaronson (1977).

The term secretion, as used here, refers only to the accumulation of enzyme activity in the cell-free medium and does not imply the nature of the mechanism of enzyme release. The term synthesis, as used here, refers to the total amount of enzyme found in the cells and the cell-free medium after a specific time of incubation. All experiments were done three or more times; typical results are presented here.

Enzyme assays and analytical procedures. All assays were carried out at $37{ }^{\circ} \mathrm{C}$. The rate of reaction was linear with respect to time and enzyme concentration under standard assay conditions.

Acid phosphatase [orthophosphoric-monoester phosphohydrolase (acid optimum); EC 3.1.3.2] and alkaline phosphatase [orthophosphoric-monoester phosphohydrolase (alkaline optimum); EC 3.1.3.1] activities were assayed with $p$-nitrophenyl phosphate as substrate as described by Patni et al. (1974). Phosphoglucose isomerase [D-glucose-6-phosphate ketol-isomerase; EC 5.3.1.9] was assayed by the method of Reithel (1966). Enzyme activities are expressed as $\mu \mathrm{mol} p$-nitrophenol liberated per min per $\mathrm{ml}$ cell-free supernatant or cell homogenate. The incubation of homogenates of $O$. danica with cycloheximide, chloramphenicol or chloramphenicol base for up to $25 \mathrm{~h}$ resulted in no loss of acid phosphatase activity. Addition of $2.5 \mathrm{~mm}-$ potassium phosphate buffer $\mathrm{pH} 5.0$ during assay with $p$-nitrophenyl phosphate had no effect on the enzyme activity. The secreted enzyme was quite stable in the extracellular medium as less than $10 \%$ of the activity was lost if extracellular medium containing acid phosphatase was incubated without cells for up to $24 \mathrm{~h}$ at $25^{\circ} \mathrm{C}$.

Protein was determined by the method of Lowry et al. (1951) with crystalline bovine serum albumin (Sigma) as a standard. Buffers were prepared according to the procedure of Gomori (1955). Organic phosphates and antibiotics were purchased from Sigma. All chemicals were of the highest purity available commercially and were used without further purification.

Analogues of chloramphenicol were obtained through the generosity of Dr M. C. Rebstock, Parke, Davis \& Co., Ann Arbor, Michigan, U.S.A. These were D-threo-1-phenyl-2-amino-1,3-propanediol; L-threo1-phenyl-2-amino-1,3-propanediol; DL-erythro-1-phenyl-2-amino-1,3-propanediol; DL-threo-1-p-phenylphenyl-2-amino-1,3-propanediol; D-threo-1-p-aminophenyl-2-amino-1,3-propanediol; D-threo-1-m-nitro- 


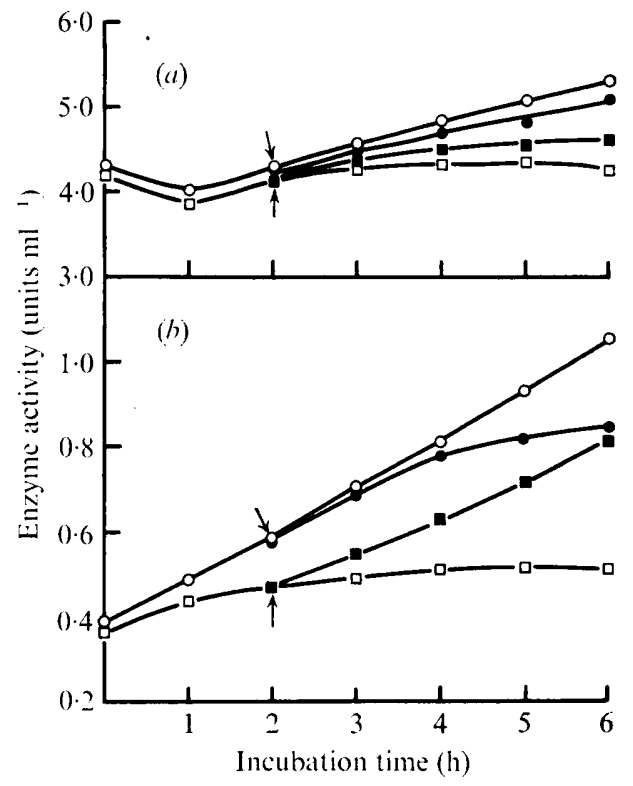

Fig. 1. Effect of cycloheximide $(100 \mu \mathrm{M})$ on the synthesis and secretion of acid phosphatase: (a) total (intracellular plus extracellular); (b) extracellular. $\bigcirc$, Control cells without cycloheximide; 0 , cycloheximide added at $2 \mathrm{~h} ; \square$, cycloheximide added at zero time; $\boldsymbol{\square}$, cycloheximide removed after $2 \mathrm{~h}$ by centrifuging the cells, washing in starvation medium and resuspending the cells in fresh starvation medium.

phenyl-2-phenyl-2-amino-1,3-propanediol; DL-1-p-nitrophenyl-2-aminoethanol; ;L-threo-1-p-nitrophenyl-2amino-1,3-propanediol; and 1,1-diphenyl-2-amino-3-propanol.

\section{RESULTS}

\section{Effect of chloramphenicol and chloramphenicol base on acid phosphatase synthesis and secretion}

Chloramphenicol slightly stimulated acid phosphatase synthesis and secretion but chloramphenicol base was far more active in this respect (Table 1). Washing chloramphenicol base-treated cells once in an equal volume of starvation medium eliminated the stimulation of acid phosphatase synthesis and secretion. None of the analogues of chloramphenicol at $1 \mathrm{mM}$ affected the synthesis or secretion of acid phosphatase. DL-threo-1-p-Phenylphenyl2-amino-1,3-propanediol and DL-threo-1-p-nitrophenyl-2-aminoethanol inhibited the acid phosphatase activity. DL-threo-1-p-Phenylphenyl-2-amino-1,3-propanediol lysed Ochromonas cells. The effect of chloramphenicol base was specific as modification of the molecule (D-threo-1-nitrophenyl-2-amino-1,3-propanediol) such as removing the nitro group from the para position of the ring, moving the nitro group to the meta position or reducing the nitro group to an amino group led to a loss of stimulatory activity. The stimulation of acid phosphatase secretion and synthesis seemed to be rather specific and not the result of cell leakage as the stimulation did not lead to an increase in $A_{\mathbf{2 6 0}}$-absorbing material, or nonsecreted cytoplasmic marker enzyme activity of phosphoglucose isomerase or alkaline phosphatase.

\section{Effect of cycloheximide on acid phosphatase synthesis and secretion}

Non-dividing Ochromonas cells suspended in starvation medium with $100 \mu \mathrm{M}$-cycloheximide at $0 \mathrm{~h}$ showed almost complete inhibition of acid phosphatase synthesis and secretion after about $2 \mathrm{~h}$ of incubation (Fig. 1); if cells were washed free of cycloheximide, the inhibition of synthesis and secretion was removed. Inhibition of acid phosphatase 


\section{Table 2. Effect of antibiotics on protein synthesis and secretion in Ochromonas danica}

Incorporation of $\left[{ }^{3} \mathrm{H}\right]$ leucine into protein was followed as described by Patni \& Aaronson (1977). Extracellular protein was harvested by adding $1 \mathrm{ml}$ of a solution containing $2 \mathrm{mg}$ albumin $\mathrm{ml}^{-1}$ followed by precipitation with $10 \%(\mathrm{w} / \mathrm{v})$ trichloroacetic acid. The precipitate was washed twice with $10 \%$ trichloroacetic acid. Results are expressed as c.p.m. min $^{-1}$; figures in parentheses represent inhibition or stimulation as a percentage of the control (no addition) after the same incubation time.

Addition

Concn

Intracellular protein

None

Chloramphenicol

Chloramphenicol base

Cycloheximide

Extracellular protein

None

Chloramphenicol

Chloramphenicol base

Cycloheximide $(\mu \mathrm{M})$

$\begin{array}{cc} & 93204 \pm 473 \\ & (100) \\ 31 & 93018 \pm 578 \\ & (100) \\ 40 & 92185 \pm 2082 \\ & (99) \\ 35 & 22554 \pm 843 \\ & (24) \\ & \\ & 477 \pm 14 \\ & (100) \\ 31 & 434 \pm 44 \\ & (91) \\ 40 & 871 \pm 101 \\ & (183) \\ 35 & 527 \pm 13\end{array}$

(111)
Incorporation of $\left[{ }^{3} \mathrm{H}\right]$ leucine into protein after:

\begin{tabular}{|c|c|c|}
\hline $2 \mathrm{~h}$ & $4 \mathrm{~h}$ & $6 \mathrm{~h}$ \\
\hline $\begin{array}{c}93204 \pm 473 \\
(100)\end{array}$ & $\begin{array}{c}208789 \pm 7110 \\
(100)\end{array}$ & $\begin{array}{c}276896 \pm 10299 \\
(100)\end{array}$ \\
\hline $\begin{array}{c}93018 \pm 578 \\
(100)\end{array}$ & $\begin{array}{c}205210 \pm 37479 \\
(98)\end{array}$ & $\begin{array}{c}294195 \pm 6748 \\
(106)\end{array}$ \\
\hline $\begin{array}{c}92185 \pm 2082 \\
(99)\end{array}$ & $\begin{array}{c}224842 \pm 22206 \\
(108)\end{array}$ & $\begin{array}{c}300238 \pm 6881 \\
(108)\end{array}$ \\
\hline $\begin{array}{c}22554 \pm 843 \\
(24)\end{array}$ & $\begin{array}{c}33126 \pm 1206 \\
(16)\end{array}$ & $\begin{array}{c}42363 \pm 1570 \\
(15)\end{array}$ \\
\hline $\begin{array}{c}477 \pm 14 \\
(100)\end{array}$ & $\begin{array}{l}3747 \pm 302 \\
\quad(100)\end{array}$ & $\begin{array}{l}5078 \pm 260 \\
(100)\end{array}$ \\
\hline $\begin{array}{c}434 \pm 44 \\
(91)\end{array}$ & $\begin{array}{c}3779 \pm 398 \\
(101)\end{array}$ & $\begin{array}{c}5421 \pm 853 \\
(107)\end{array}$ \\
\hline $\begin{array}{l}871 \pm 101 \\
(183)\end{array}$ & $\begin{array}{l}5855 \pm 110 \\
\quad(156)\end{array}$ & $\begin{array}{l}9527 \pm 471 \\
\quad(188)\end{array}$ \\
\hline $527 \pm 13$ & $3445 \pm 12$ & $3818 \pm 99$ \\
\hline
\end{tabular}

(91)

synthesis and secretion was also observed if cycloheximide was added during incubation (Fig. 1). Concentrations of cycloheximide as low as $10 \mu \mathrm{M}$ inhibited synthesis and secretion of acid phosphatase.

\section{Effect of antibiotics on the incorporation of $\left[{ }^{3} \mathrm{H}\right]$ leucine into cellular and extracellular protein}

Cycloheximide inhibited the incorporation of $\left[{ }^{3} \mathrm{H}\right]$ leucine into protein; intracellular protein synthesis was inhibited much more than protein secretion (Table 2). Chloramphenicol stimulated protein synthesis and secretion slightly; chloramphenicol base also stimulated protein synthesis slightly but protein secretion was appreciably stimulated (Table 2).

\section{DISCUSSION}

Cycloheximide inhibits protein synthesis in most eukaryotic systems, but other cell functions may also be affected (McMahon, 1975; also see Introduction). In the present study, cycloheximide inhibited acid phosphatase synthesis and secretion over a wide range of concentrations; synthesis, however, was more sensitive to cycloheximide than was secretion in that it did not recover from this inhibition after washing. This was also borne out by the isotope experiment (Table 2).

Stimulation of protein synthesis or activity, but not secretion, in a variety of eukaryotic systems by inhibitors of protein synthesis was assumed to be due to (i) prevention of enzyme or hormone degradation by cycloheximide (Kenney, 1967; Jervell \& Seglen, 1969; Szepesi \& Freedland, 1969) or (ii) inhibition of $70 \mathrm{~S}$ ribosome protein synthesis by chloramphenicol with the accompanying sparing of amino acids for use with $80 \mathrm{~S}$ ribosomes or (iii) inhibition 
of $80 \mathrm{~S}$ ribosome protein synthesis and sparing of amino acids for use with $70 \mathrm{~S}$ ribosomes (Kadenbach, 1971; Honeycutt \& Margulies, 1973; Givan, 1974). In O. danica acid phosphatase synthesis and secretion were stimulated by chloramphenicol base within $2 \mathrm{~h}$. Early secretion seemed to be at the expense of the cell pool but after $6 \mathrm{~h}$ both intracellular and extracellular acid phosphatase activity had increased sufficiently to indicate that both were stimulated (Table 1). As chloramphenicol had no inhibitory effect on acid phosphatase synthesis and secretion we may assume that $70 \mathrm{~S}$ ribosomes were not involved. Furthermore, most of the acid phosphatase is found in the plasma membrane and soluble portions of Ochromonas and very little in the organelles (Patni, Billmire \& Aaronson, 1974) which offers further support for acid phosphatase synthesis by $80 \mathrm{~S}$ ribosomes. As chloramphenicol base provides only $2 \%$ of the antimicrobial activity of the intact chloramphenicol molecule (Hahn, 1967), stimulation by chloramphenicol base is unlikely to be due to a sparing of amino acids for $80 \mathrm{~S}$ ribosome protein synthesis. The stability of acid phosphatase activity in the extracellular medium over $24 \mathrm{~h}$ in the presence of other hydrolases suggests that inhibition of enzyme degradation is unlikely to be the site of action of chloramphenicol base (Shio, 1971). Chloramphenicol base stimulated the secretion of labelled protein without appreciably stimulating intracellular protein synthesis (Table 2), and it stimulated both acid phosphatase synthesis and secretion (Table 1). It is possible that the stimulation of acid phosphatase synthesis and secretion by chloramphenicol base may be attributed to a mechanism other than inhibition of enzyme degradation or sparing of amino acids for $80 \mathrm{~S}$ ribosome protein synthesis. This mechanism remains to be described.

This work was supported by the National Science Foundation Grant BMS 74-08918 to S.A. and in part by the National Institutes of Health Grant 5-S05-RR-07064-09 to Queens College.

\section{REFERENCES}

Aaronson, S. \& Patni, N. J. (1976). The role of surface and extracellular phosphatases in the phosphorus requirement of Ochromonas. Limnology and Oceanography 21, 838-845.

Beck, W. T., Bellantone, R. A. \& Canellakis, E. S. (1973). Puromycin stimulation of rat liver ornithine decarboxylase activity. Nature, London 241, 275-277.

Benson, P. F. \& Young, P. M. (1968). Effect of actidione on hormonal induction and development of rat liver 1-tyrosine-2-oxoglutarate aminotransferase activity. Biochemical Journal 106, 54 P.

CiHAK, A. (1975). Character of the stimulatory response of uridine kinase in rat livers to cycloheximide treatment. European Journal of Biochemistry 58, 3-7.

Dunlop, P. C. \& Roon, R. J. (1975). L-Asparaginase of Saccharomyces cerevisiae: an extracellular enzyme. Journal of Bacteriology 122, 1017-1024.

Fiala, S. \& Fiala, E. (1965). Hormonal dependence of actidione (cycloheximide) action. Biochimica et biophysica acta 103, 699-701.

Givan, A. L. (1974). Ribulose diphosphate carboxylase synthesis in Chlamydomonas reinhardii: inhibition by chloramphenicol and stimulation by cycloheximide. Planta 120, 181-188.

GoMORI, G. (1955). Preparation of buffer for use in enzyme studies. Methods in Enzymology 1, 138146.

HaHn, F. E. (1967). Chloramphenicol. In Antibiotics, vol. I, pp. 308-330. Edited by D. Gottlieb and P. D. Shaw. New York: Springer-Verlag.

Honeycutt, R. C. \& Margulies, M. M. (1973).
Protein synthesis in Chlamydomonas reinhardi: evidence for synthesis of proteins of chloroplastic ribosomes on cytoplasmic ribosomes. Journal of Biological Chemistry 248, 6145-6153.

Jervell, K. F. \& Seglen, P. O. (1969). Tyrosine transaminase degradation in perfused liver after inhibition of protein synthesis by cycloheximide. Biochimica et biophysica acta 174, 398-400.

KADENBACH, B. (1971). Biosynthesis of mitochondrial cytochromes. In Autonomy and Biogenesis of Mitochondria and Chloroplast, pp. 360-371. Edited by N. K. Boardman, A. W. Linnane \& R. M. Smillie. Amsterdam: North-Holland Publishing Company.

KENNEY, F. T. (1967). Turnover of rat liver tyrosine transaminase: stabilization after inhibition of protein synthesis. Science 156, 525-527.

Lowry, O. H., Rosebrough, N. J., FarR, A. L. \& Randall, R. J. (1951). Protein measurement with the Folin phenol reagent. Journal of Biological Chemistry 193, 265-275.

MCMaHon, D. (1975). Cycloheximide is not a specific inhibitor of protein synthesis in vivo. Plant Physiology 55, 815-821.

Nose, K., Nitta, K., Takaoka, T. \& Katsuta, H. C. (1974). Release of cytoplasmic enzyme into culture fluid. Journal of Cellular Physiology 84, 269-274.

Patni, N. J. \& Aaronson, S. (1974). Partial characterization of the intra- and extracellular acid phosphatase of an alga, Ochromonas danica. Journal of General Microbiology 83, 9-20.

Patni, N. J. \& Aaronson, S. (1977). Stimulation 
of acid phosphatase secretion in a lower eukaryote, Ochromonas danica, by specific organic phosphates. Biochimica et biophysica acta 478, 209-214.

Patni, N. J., Aaronson, S., Holik, H. J. \& Davis, R. H. (1974). Existence of acid and alkaline phosphohydrolase activity in the phytoflagellate Ochromonas danica. Archives of Microbiology 97, 63-67.

Patni, N. J., Brllmire, E. \& Aaronson, S. (1974). Isolation of the Ochromonas plasma membrane and identification of several membrane enzymes. Biochimica et biophysica acta 373, 347-355.

ReITHEL, F. J. (1966). Phosphoglucose isomerase. Methods in Enzymology 9, 565-568.

SHo, H. (1971). Extracellular secretion of acid hydrolases by the phytoflagellate Ochromonas danica.
M.A. thesis, Queens College, City University of New York, U.S.A.

SisLeR, H. D. \& SiEGEL, M. R. (1967). Cycloheximide and other glutarimide antibiotics. In Antibiotics, vol. I, pp. 283-307. Edited by D. Gottlieb and P. D. Shaw. New York: Springer-Verlag.

SZEPESI, B. \& FREEDLAND, R. A. (1969). Control of tyrosine- $\alpha$-ketoglutarate transaminase synthesis in rat liver: studies of superinduction in force-fed rats. Journal of Nutrition 97, 255-259.

UekI, K. \& SATo, S. (1971). Effect of inorganic phosphate on the extracellular acid phosphatase activity of tobacco cells cultured in vitro. Physiologia plantarum $24,506-511$.

VARNER, J. E. \& MeNSE, R. M. (1972). Characteristics of the process of enzyme release from secretory plant cells. Plant Physiology 49, 187-189. 